\title{
Aleksandr KOCZETKOW
}

Moskiewski Uniwersytet Państwowy im. M. Łomonosowa

apkoch@mail.ru

\section{ROSYJSKA ELITA: \\ HISTORIA I WSPÓŁCZESNOŚĆ}

ABSTRACT The Russian elite: history and the present day

In the article author analyzes the process of formation of the Russian elite during the main stages of historical development of Russia, especially the mechanisms and methods of recruitment. Special attention is paid to the formation of post-Soviet elites, the comparative analysis of peculiarities of formation of the Soviet and modern Russian elite.

Keywords: the elite, the ruling elite, democracy, power, counter-elite, state

Słowa kluczowe: elita, elita rządząca, demokracja, władza, kontrelita, państwo 
$\mathbf{R}$ eguły transformacji i wymiany elit, ich wpływ na określenie systemu polityczRnego kraju są wyraźnie widoczne w ciągu ponad tysiącletniej historii Rosji. Na jej przykładzie można ustalić zależność między jakością elity a stabilnością systemu społeczo-politycznego i stopniem jego otwartości. Gaetano Mosca napisał, że w społeczeństwach, które znajdują się w początkowych stadiach rozwoju, osoby, które wykazuja więcej zdolności w rzemiośle wojennym, tatwo osiagaja przewage nad swymi towarzyszami ${ }^{1}$. Jako typowy przykład elity wojskowej, historycznie pierwszej, uczony wskazuje elitę w Rosji. Wasilij Kluczewskij również uważał, że wyższą klasę społeczeństwa na Rusi, którym rządził książę kijowski, tworzyła drużyna książęca. Dzieliła się na wyższą warstwę („mężów książęcych” lub bojarów) i niższą - otroków (gridinów). Początki rosyjskiej elity to co najmniej XI w. W Prawdzie Ruskiej (Pycckas nравда) Jarosława Mądrego opisane jest rozwarstwienie społeczne ludności oraz prawa i przywileje elity. W dokumencie tym wyraźnie określono, że wobec księcia ludzie dzielą się na dwa stany: „mężów książęcych” i pospólstwo. Pierwsi służyli księciu, tworzyli jego drużynę, stan najwyższy, uprzywilejowany, przy pomocy którego książęta rządzili swoimi księstwami, bronili ich przed wrogami; była to swego rodzaju książęca elita. To nie przypadek, że życie „męża książęcego” chroniła podwójna wira ${ }^{2}$ (grzywna).

Wśród „mężów książęcych” pojawia się klasa wielkich właścicieli ziemskich - bojarów, którzy korzystali z wielu przywilejów. Wyższym rangą przedstawicielom drużyny książęcej książę powierzał funkcje administracyjne, wysyłał do ziem i włości ${ }^{3} \mathrm{w}$ swoim księstwie „na karmienie” („кормление”) na wynagrodzenie. Ci ludzie stawali się coraz mniej zależni od centrum. Dotyczy to w szczególności feudalnych książąt, którzy czuli się niezależnymi królewiętami we własnych wotczynach. Charakterystyczne było rozdrabnianie nadanej przez księcia ziemi z pokolenia na pokolenie. Rozdrobnienie feudalne Rusi doprowadziło do jej osłabienia i stało się jedną z głównych przyczyn porażki w walkach ze Złotą Ordą.

Г. Моска, Правящий класс, „Социологические исследования” 1994, nr 10, s. 189.

2 Wira - w okresie staroruskim, wspominana jeszcze w dokumentach z 1584 r., kara pieniężna za mordertswo lub okaleczenie ciała, płacona księciu. Jej wysokość była uzależniona od statusu społecznego ofiary. Za zabójstwo człowieka ze stanu niskiego kara opiewała na 40 grzywien srebra, natomiast za zabójstwo przedstawiciela elity obowiązywała kara w podwójnej wysokości. Zob. Bupa, [w:] Энииклопедический Словарь Ф. А. Брокгауза и И. А. Ефрона, Санкт-Петербург 1890-1907, [online] http://www.vehi.net/brokgauz/, 10 X 2015 [przypis Redakcji].

3 Wołość - w okresie staroruskim terytorium, na które rozciąga się władza księcia, lub gmina w obrębie tego terytorium. Zob. С. Аатышев, Волость, [w:] Энииклопедический Словарь Ф. А. Брокгауза и И. А. Ефрона, Санкт-Петербург 1890-1907, [online] http://www.vehi.net/brokgauz/, 10 X 2015 [przypis Redakcji].

4 „Karmienie” - system administracji lokalnej w okresie staroruskim, oparty na obowiązku utrzymywania przez lokalne społeczności urzędników wyznaczonych przez księcia. System został formalnie zniesiony ukazem z 1555 r. Zob. M. А., Кормление, [w:] Энциклопедический Словарь Ф. А. Брокгауза и И. А. Ефрона, Санкт-Петербург 1890-1907, [online] http://www.vehi.net/ brokgauz/, 10 X 2015 [przypis Redakcji]. 
W okresie wzmocnienia Moskwy, która stała się centrum jednoczącym ziemie ruskie, wyraźnie zmienił się skład, struktura i mentalność polityczno-administracyjnej elity Rusi. Jednoczeniu Rusi towarzyszyło przechodzenie na służbę Moskwy książąt i bojarów z przyłączanych księstw, a także przyjęcie służby u moskiewskiego władcy przez szlachetnie urodzonych cudzoziemców z Litwy, księstw niemieckich i Złotej Ordy. Wielki książę, a od Iwana IV - car, mianował namiestników zarządzających poszczególnymi regionami, mianował bojarów i innych członków elity na lukratywne stanowiska, zapewniające im „karmienie”. Należy zaznaczyć, że tradycja „karmienia”, która głęboko zakorzeniła się w rosyjskiej elicie i w istocie była zalegalizowaną korupcją, miała destrukcyjny wpływ i na samą elitę, i na społeczeństwo w ogóle. Istniały zarówno obiektywne przyczyny tego zjawiska (konieczność stworzenia rozbudowanej elity administracyjnej w rozległym kraju i brak pieniędzy na wynagradzanie jej za służbę z powodu ogromnych wydatków na niekończące się wojny), jak i subiektywne (niezwykła gotowość członków elity, aby czerpać maksymalne korzyści z zajmowanych stanowisk administracyjnych).

Przy tworzeniu scentralizowanego państwa rosyjskiego zmianie uległa rola monarchy; nie jest już pierwszym wśród innych książąt, lecz samodzierżcą, „pomazańcem Bożym", rządzącym autorytarnie, łamiąc opór nieposłusznych książąt i bojarów. Zmienia się rola i samoświadomość elity polityczno-administracyjnej, która w coraz większym stopniu dąży do tego, by rządzić Ziemią Ruską nie w częściach i nie pojedynczo, jak ich przodkowie, lecz całościowo - za pośrednictwem władzy centralnej.

Rosja, kraj o ogromnym terytorium, którego rozwój został zahamowany przez jarzmo tatarsko-mongolskie, zmuszona była do nieustannej obrony przed najazdami koczowniczych plemion na Wschodzie (swoje terytoria również powiększała przeważnie na Wschodzie) i przed ekspansją Zachodu. Niesprzyjające warunki klimatyczne i demograficzne, skąpe nadwyżki produkcji, w połączeniu z koniecznością obrony niezależności przez wieki, uformowały państwo rosyjskie na kształt oblężonego obozu. Rosja, aby przetrwać, musiała uciekać się do mobilizacyjnego, narzucanego odgórnie typu rozwoju, do modelu modernizacji, który wymagał ogromnego natężenia wszystkich sił narodu, przy tym - w warunkach ciągłego braku pieniędzy w skarbcu.

W przypadku mobilizacyjnego typu rozwoju najważniejszym zadaniem władzy jest inicjowanie impulsów do modernizacji pod naciskiem wewnętrznych lub zewnętrznych kryzysów politycznych lub ich kumulacji. Ten typ rozwoju zakłada autorytarny, zmilitaryzowany system polityczny o pionowej hierarchicznej strukturze zarządzania, który opiera się na przymusowych metodach rozwiązywania problemów.

W związku z tym, w życiu społeczeństwa rosyjskiego stale istniał priorytet reguł politycznych przed gospodarczymi, co sprawiło, że rekrutowanie elity rządzącej odbywało się na zasadzie „służby” i ukształtowało w związku z tym charakterystyczny typ społeczno-psychologiczny jej przedstawicieli. Autorytarna władza oczekiwała autorytarnych elit, które miały być jej pasem transmisyjnym ${ }^{5}$.

Por. О. Гаман-Голутвина, Политические элиты России. Вехи исторической эволюиии, Москва 1998, s. 63, Политология России. 
Dynastia Romanowów kontynuowała kurs na wzmocnienie władzy samodzierżawnej. Za panowania cara Michała, a zwłaszcza cara Aleksego został stworzony aparat służebnej biurokracji nieuchronnie wypierający elitę arystokratyczną. Utożenie soborowe (Соборное уложение) z 1649 r. uporządkowało reguły scentralizowanego zarządzania krajem poprzez system prikazów ${ }^{6}$, kierujących sprawami państwa.

Radykalne zmiany w systemie zarządzania państwem i w konsekwencji - w strukturze elity polityczno-administracyjnej, nastąpiły za panowania Piotra I. Piotr miał świadomość, że tradycyjny system zamkniętej elity to ślepy zaułek, który nie pozwala na realizację śmiałych planów reformatorskich. Potrzebna mu była nowa, energiczna elita kierownicza, zdolna do przezwyciężenia inercji tradycjonalizmu. Car umiał znajdywać ludzi o talentach organizatorskich, włączając do elity najzdolniejszych przedstawicieli niższych warstw społecznych. Proces modernizacji społeczeństwa z konieczności okazał się także procesem modernizacji elity.

Kurs na unowocześnienie kraju, obrany przez Piotra I, wymagał zastąpienia elity tradycyjnej - elitą odpowiadającą wyzwaniom modernizacji. Piotr I stworzył rozbudowany biurokratyczny system zarządzania krajem, w dużej mierze oparty na modelu zarządzania istniejącym w krajach Europy Zachodniej. Biurokracja owa została powołana do tego, aby służyć jako pas transmisyjny absolutystycznej polityki wewnętrznej i zagranicznej. Polityka modernizacji wymagała rezygnacji z formującej elitę zasady „miestniczestwa” („местничество”) ${ }^{7}$ i stworzenia jednolitej zhierarchizowanej struktury urzędniczej. Dokumentem zapewniającym umocowanie prawne tej hierarchii była „Tabela rang wszystkich urzędów wojskowych, państwowych i dworskich” („Табель о рангах всех чинов воинских, статских и придворных”) z 1722 r. Dokument ten stanowil, że głównym kryterium kształtowania elity administracyjnej i wojskowej nie powinno być arystokratyczne pochodzenie, lecz kwalifikacje, przydatność służbowa, osobiste zasługi.

Kształtując elitę na podstawie zasady hierarchizacji pionowej, państwo stworzyło jeden z najważniejszych mechanizmów sprawowania scentralizowanej władzy absolutnej. Reformy Piotra I, wprowadzane odgórnie (jak zresztą wszystkie reformy w Rosji), wymagały elit typu autorytarnego, w pełni zależnych od władzy monarchy, sprawujących scentralizowaną, silną władzę, otrzymujących nagrody i przywileje za służbę. Szlachta stała się podstawową elitą. W nagrodę za służbę otrzymywała pieniądze lub majątki, nadawane przez władcę.

W ciągu 300 lat panowania dynastii Romanowów skład i struktura rosyjskiej elity politycznej i administracyjnej ulegały istotnej zmianie. Za panowania pierwszych Romanowów (XVII w.) najważniejsze kwestie państwowe były rozstrzygane na Soborach

„Prikazy” - nazwa organów administracji centralnej w okresie Rusi Moskiewskiej (XV-XVII w.).Zob. J. Ochmański, Dzieje Rosji do roku 1861, Warszawa 1986, s. 100-102 [przypis Redakcji].

„Miestniczestwo” - w okresie Rusi Moskiewskiej zasada mianowania na stanowiska państwowe w zależności od znakomitości rodziny, pozycji, jaką na służbie carskiej zajmowali przodkowie pretendenta do stanowiska, z uwzględnieniem jego miejsca w genealogicznej hierarchii swojego rodu. Zob. И. А. Исаеев, История государства и права России, Москва 2004, s. 93-94; L. Bazylow, Historia Rosji, t. 1, Warszawa 1983, s. 177 [przypis Redakcji]. 
Ziemskich, w których uczestniczyli przedstawiciele elity centralnej i elit lokalnych, najznaczniejszymi reprezentantami bojarstwa byli członkowie Dumy Bojarskiej, pełniącej przy carze funkcje doradcze. W XVIII w. Rosja staje się imperium i bojarstwo ulega rozkładowi. Imperator dysponuje nieograniczoną władzą, system organów zarządzania państwem budowany był na podstawie zasady centralizacji biurokratycznej. Za czasów Piotra w miejsce Dumy Bojarskiej został powołany Senat, który podejmował decyzje w kwestiach administracyjnych, ustawodawczych i sądowych. W XVIII w., zdaniem Wasilija Kluczewskiego, miejsce bojarstwa zajęły nowe wyższe sfery urzędnicze, składające się z wysłużonych działaczy administracyjnych, którzy przejęli pewne polityczne zapędy arystokracji i starali się ze zwykłego narzędzia przekształcić w klasę rządzącą, w samodzielną siłę polityczną. W związku z tym można ich nazwać arystokracją urzędniczą ${ }^{8}$.

Po stłumieniu powstania dekabrystów, których można uważać za kontrelitę, starającą się obalić samodzierżawie i system pańszczyźniany, utrwalił się wojskowo-biurokratyczny absolutyzm Mikołaja I. Biurokracja ostatecznie przekształciła się w samowystarczalną kastę, starającą się podporządkować sobie wszystkie aspekty życia człowieka.

Klęska Rosji w wojnie krymskiej ukazała zacofanie społeczne i technologiczne, zgniliznę wojskowo-biurokratycznej machiny państwa rosyjskiego. Aleksander II podjął próbę zliberalizowania systemu rosyjskiego zarządzania państwem, zmodernizowania jej elit. Największa z reform to zniesienie pańszczyzny. Znaczące były także takie reformy, jak reforma samorządu terytorialnego (ziemstwa) czy reforma sądownictwa, która była pierwszym krokiem w kierunku państwa prawa. Zainicjowane reformy zostały przerwane przez zabójstwo cara i przewagę konserwatywnej elity, co utrudniło proces liberalizacji.

Przepaść między ludem i elitą rosła i osiągnęła apogeum za panowania Mikołaja II, znajdując wyraz w rewolucji XX w. Podczas rewolucji lat 1905-1907 Mikołaj II zmuszony był poczynić znaczne ustępstwa na rzecz konstytucyjnego ograniczenia samodzierżawia i powołania Dumy Państwowej. Niemniej jednak elita rządząca zachowała swój charakter stanowy; szlachta, mimo swego niezaprzeczalnego osłabienia i zubożenia, nadal zajmowała wśród elity główną pozycję. Elita rządząca nie mogła dostosować się do zmienionej sytuacji, do wymagań społeczeństwa industrialnego i ciągle pozostawała w konflikcie z Dumą Państwową. Do tego doszły sprzeczności w obrębie samej elity, przy słabym i niezdecydowanym carze (antynomie elity rządzącej i tej części elity politycznej, która pojawiła się w wyniku nowego dla Rosji trybu - wyborów do Dumy Państwowej). Wysiłki opozycji w Dumie i krytyka władzy przez opozycję liberalną i socjalistyczną ( $w$ wielu przypadkach ta krytyka była sprawiedliwa) zostały zwieńczone sukcesem. Elita rządząca całkowicie zaprzepaściła zaufanie narodu, straciła legitymację w jego oczach i w czasie rewolucji lutowej $1917 \mathrm{r}$. nie znalazły się poważne siły społeczne, które wspartyby upadający system.

Rewolucja październikowa doprowadziła do chyba najpełniejszej, najradykalniejszej i najszybszej zmiany elit w historii ludzkości, bardziej radykalnej niż podczas re-

8 Por. В. КАючевский, Сочинения..., t. 8, wykład 79. 
wolucji francuskiej 1789-1793. Zamknięta, osłabiona szlachecko-biurokratyczna elita carska ulegała degradacji, wykazała brak woli politycznej i niezdolność do zarządzania wielkim krajem, do jego modernizacji, do wchłonięcia najlepszych przedstawicieli warstw „niższych”. Jak pisał na ten temat Pitirim Sorokin, degenerująca się klasa rządząca uparcie odmawiała współudziału utalentowanym samorodkom z innych warstw, nie chcąc ograniczyć swoich praw, gotowa odrzucić wszystkich utalentowanych przybyszów.

Bolszewicy, którzy zwyciężyli w rewolucji październikowej, po przejęciu władzy sami przekształcili się w nową elitę społeczną. Już Michaił Bakunin pisał, że panowanie dyktatury proletariatu, propagowane przez Karola Marksa, będzie despotyzmem rzqdzacej mniejszości, pokrywanym demagogicznymi frazami, że wyraża ona wolę narodu. Zdaniem Bakunina, kiedy tylko byli pracownicy staną się władcami bądź przedstawicielami ludu, przestaną być pracownikami i będą patrzeć na cały świat robotniczy $\mathrm{z}$ wysokości państwa, już nie będą reprezentować ludzi, ale siebie i swoje pretensje do rządzenia ludem ${ }^{10}$.

Struktura organizacyjna nowej władzy okazała się na wskroś elitarna. Partia rządząca, jak sugerował Włodzimierz Lenin, to waska warstwa funkcjonariuszy partyjnych jej elita oraz szeroka warstwa członków partii, wypełniających decyzje jej kierownictwa - taki był zalążek przyszłej „nowej klasy”. Gdy partia doszła do władzy, jej elitarna struktura została powielona w skali całego kraju. Za czasów Lenina stworzono specjalną klasę rządzącą - nomenklaturę (wykaz stanowisk kierowniczych, których obsadzenie musiało być zatwierdzone przez organy partii). Stalin udoskonalił proces reprodukcji elity radzieckiej. Nomenklatura była zorganizowana według ściśle hierarchicznych zasad, wykazywała wysoki stopień integracji dzięki wspólnej ideologii, wysoki poziom selekcji zawodowej i niski stopień konfliktowości pomiędzy grupami wewnątrz elity. Milovan Dżilas nazwał ją nowa klasą. Uważał, że „system komunistyczny” stanowi podstawę do powstania nowej klasy uprzywilejowanej, którą tworzy biurokratyczna elita partii i państwa, posiadająca nieograniczoną władzę ${ }^{11}$.

W drugiej połowie lat 80. rozpoczął się w ZSRR proces szybkiego kształtowania kontrelity, złożonej z liderów i działaczy różnorodnych ruchów demokratycznych, przedstawicieli inteligencji twórczej i naukowej. W wyniku pieriestrojki nastąpiły znaczące zmiany w składzie elity, ale nie miały one charakteru wymiany elit, lecz były transformacją tej samej elity. Wymiana elit pozostała kwestią ciągle aktualną. Jednym z efektów pieriestrojki było przekonwertowanie władzy elity rządzącej na stan posiadania. Kolejnym podniesionym problemem było przekonwertowanie własności na władzę.

Nowa rosyjska elita polityczna utworzyła się wewnątrz starego systemu radzieckiego jako rodzaj kontrelity w różnych grupach na poziomie federalnym. Początkiem był

Por. П. Сорокин, Человек, цивилизация, общество, Москва 1992, s. 291.

10 Рог. С. УАарцев, Политическал и правовая теория анархизма в России. История и современность, Москва 1994, s. 143.

11 Por. М. Ажилас, Аицо тоталитаризма, przeł. П. Щетинин, Е. Полак, О. Кирилмова, Москва 1992; М. Восленский, Номенклатура, Москва 2005. 
29 maja 1990 r., gdy na przewodniczącego Rady Najwyższej Rosyjskiej Federacyjnej Socjalistycznej Republiki Radzieckiej (RFSRR) został wybrany Borys Jelcyn, który przejął funkcje głowy państwa. Drugi etap nastąpił po wybraniu Jelcyna na prezydenta Rosji w dniu 12 czerwca 1991 r. Jelcyn stworzył własną administrację, liczącą 1,5 tys. osób i zbliżającą się pod względem liczebności do aparatu dawnego Komitetu Centralnego KPZR. Trzecim krokiem w tworzeniu centralnej rosyjskiej elity politycznej były wybory deputowanych do Dumy Państwowej i Rady Federacji 12 grudnia 1993 r. Czwartym - wybory parlamentarne w 1995 r. i wybory prezydenckie w 1996 r. ${ }^{12}$ Kształtowanie się nowej rosyjskiej elity politycznej było w dużej mierze związane z procesem wyborczym, co jest charakterystyczne dla Rosji postradzieckiej.

Ważnym czynnikiem, który miał daleko idące konsekwencje dla formowania się rosyjskiej elity rządzącej, było zdelegalizowanie KPZR w 1991 r., co spowodowało likwidację tradycyjnych instytucji władzy radzieckiej i instytucji nomenklatury oraz przekazanie pełnomocnictw związkowych organów władzy - rosyjskim.

Rosyjscy politolodzy wyróżniają dwa etapy kształtowania się elity postradzieckiej: „jelcynowski” i „putinowski”. Olga Krysztanowskaja - autorka książki Anatomia rosyjskiej elity (Анатомия российской элитьь) - zauważa, że w ciągu dziewięciu lat rządów (1991-1999) Borys Jelcyn nie zdołał zintegrować władzy najwyższej. Przy tym żadna struktura państwa nie stała się dominująca. W warunkach próżni władzy grupy nieformalne i klany podejmowały funkcje państwowe, konkurując między sobą o prawo do występowania w imieniu prezydenta. Zdaniem uczonej $w$ okresie jelcynowskim wtadza najwyższa ulegta rozpadowi. Dyfuzja wtadzy nie doprowadzita do demokratycznego podziatu wtadzy, a do chaosu w zarzadzaniu ${ }^{13}$.

Charakterystyczne dla etapu „putinowskiego” jest wyeliminowanie przyczyn, które doprowadzily do zniszczenia pionowej struktury zarządczej za prezydentury Borysa Jelcyna. Nowy prezydent przywrócił centrum federalnemu znaczącą władzę nad regionami, poszerzył bazę wsparcia centrum w terenie i określił sposoby przywrócenia mechanizmów zarządzania terytoriami, formalnie nie naruszając przy tym zasad demokracji. Stworzony został sterowny, uporządkowany system władzy wykonawczej. Jeśli za czasów Jelcyna władza się decentralizowała, przemieszczając się od centrum do regionów, to za czasów W. Putina znów zaczęła wracać do centrum, tendencje odśrodkowe ustąpiły miejsca dośrodkowym.

Badacze odnotowują, że współczesna elita rządząca w Rosji różni się od radzieckiej pod względem wielu ważnych właściwości: genezy, modeli rekrutowania, składu społeczno-zawodowego, organizacji wewnętrznej, mentalności politycznej, charakteru relacji ze społeczeństwem, poziomu potencjału reformatorskiego ${ }^{14}$.

Skład osobowy elity politycznej współczesnej Rosji zmieniał się, jednakże struktura stanowisk pozostała praktycznie bez zmian. Elita polityczna Rosji jest reprezentowana

12 Por. Э. Шнайдер, Политическал система Российской Федерации, Москва 2002.

13 О. Крыштановская, Анатомия российской элить, Москва 2005, s. 235.

14 Por. nр. Т. Заславская, Современное российское общество. Сочиальный механизм трансформации, Москва 2004, s. 289. 
przez prezydenta, premiera, członków rządu, deputowanych do Zgromadzenia Federalnego, sędziów Sądu Konstytucyjnego, Sądu Najwyższego, Naczelnego Sądu Arbitrażowego, administrację prezydenta, członków Rady Bezpieczeństwa, pełnomocników prezydenta w okręgach federalnych, zwierzchników struktur władzy w podmiotach federacji, zwierzchników służby dyplomatycznej i dowództwo wojskowe, niektóre inne stanowiska państwowe, kierownictwo partii politycznych i dużych organizacji społecznych, a także inne wpływowe osobistości.

Liczebność elity rządzącej w Rosji nie jest stała. Na przykład nomenklaturę KC KPZR (w 1981 r.) tworzyło około 400 tys. ludzi. Wyższa nomenklatura (nomenklatura Biura Politycznego KC KPZR) liczyła około 900 osób. To ona w rzeczywistości była elitą rządzącą w ZSRR. Nomenklatura Sekretariatu Komitetu Centralnego składała się z 14-16 tys. ludzi. Nomenklatura kontrolno-ewidencyjna (nomenklatura wydziałów KC KPZR) liczyła 250 tys. osób. Resztę stanowiła nomenklatura niższych komitetów partyjnych. Tak więc klasa polityczna w okresie radzieckim stanowiła około $0,1 \%$ ogółu ludności kraju.

Na początku XXI w. liczebność klasy politycznej w Rosji (liczba urzędników państwowych) wzrosła trzykrotnie (podczas gdy liczba ludności zmniejszyła się o połowę) i wynosiła 1,2 mln osób, czyli 0,8\% całkowitej liczby populacji. Liczebność elity rządzącej wzrosła przy tym z 900 do 1060 osób $^{15}$.

Elita rządząca w $1991 \mathrm{r}$. rekrutowała się głównie z grona inteligencji $(53,5 \%)$ i kierownictwa gospodarczego (około 13\%). W przejściowym okresie rządów Jelcyna (lata 1991-1993) zmalało znaczenie robotników, chłopów, inteligencji, kierownictwa gospodarczego, pracowników ministerstw i resortów. Znaczenie innych, przeciwnie, rosło, dotyczy to: administracji regionalnej, współpracowników resortów siłowych i ochrony prawa, a zwłaszcza - biznesmenów ${ }^{16}$.

Z powodu braku wsparcia ze strony państwa takie grupy społeczne, jak robotnicy i chłopi, zostały niemal całkowicie wyparte z pola politycznego, gwałtownie spadł odsetek kobiet i młodzieży, których wysoki procent udziału w organach władzy był poprzednio sztucznie podtrzymywany przez KPZR.

Szereg badań (S. A. Granowskij, E. Schneider) wskazuje, że fundamentem nowej rosyjskiej elity rządzącej są głównie przedstawiciele drugiego i trzeciego szczebla dawnej nomenklatury radzieckiej, przekazujący nowej elicie politycznej niezbędną wiedzę specjalistyczną i doświadczenie. Borys Jelcyn otaczał się młodymi naukowcami, znakomicie wykształconymi politykami miejskimi, ekonomistami i prawnikami. Gwałtownie spadł odsetek mieszkańców wsi w jego otoczeniu ${ }^{17}$.

Zmiany dotyczyły nie tylko poziomu wykształcenia elit, ale także typu ich wykształcenia. Elita breżniewowska była technokratyczna. Zdecydowana większość przywód-

15 Н. Баранов, Правящал элита современной России, „Без темы. Научный общественно-политический журнал” 2006, nr 2, s. 145-146.

16 О. Крыштановская, Анатомия..., s. 146-153.

17 Por. С. Грановский, Пррикладная политология. Учебное пособие, Москва 2004; Э. Шнайдер, Политическал система... 
ców partyjnych i państwowych w latach 80 . miała wykształcenie inżynierskie, wojskowe lub rolnicze. Za czasów Michaiła Gorbaczowa zmniejszył się odsetek technokratów, ale nie w wyniku zwiększenia liczby humanistów, lecz wzrostu odsetka członków partii, którzy otrzymali wyższe wykształcenie partyjne. Wreszcie, gwałtowny spadek odsetka osób, które otrzymały wykształcenie techniczne (prawie 1,5 raza), miał miejsce za czasów B. Jelcyna. Zmiany te następowały w kontekście niezmienionego systemu edukacji w Rosji, gdzie nadal większość uczelni ma profil techniczny.

Za czasów Putina w elicie rządzącej znacznie zwiększył się odsetek osób w mundurach: co czwarty przedstawiciel elity to wojskowy (za prezydentury Jelcyna odsetek wojskowych wynosił 11,2\%, za Putina - 25,1\%). Tendencja ta zbiegła się z oczekiwaniami społecznymi, ponieważ reputacja wojskowych jako uczciwych, odpowiedzialnych, niezaangażowanych politycznie profesjonalistów korzystnie odróżniała ich od innych elitarnych grup, których wizerunek kojarzył się z kradzieżą, korupcją, demagogią. Masowe angażowanie wojskowych do służby państwowej wynikało także z braku rezerw kadrowych.

Główne cechy charakterystyczne elity putinowskiej to zmniejszenie odsetka „intelektualistów" ze stopniami naukowymi (za czasów Borysa Jelcyna - 52,5\%, za czasów Władimira Putina - 20,9\%), zmniejszenie i tak już niskiego udziału kobiet w elicie (z 2,9\% do 1,7\%), „prowincjonalizacja” elity i gwałtowny wzrost liczby wojskowych, których zaczęto nazywać „siłowikami” (przedstawiciele Sił Zbrojnych, Federalnej Służby Bezpieczeństwa, Wojsk Ochrony Pogranicza, Ministerstwa Spraw Wewnętrznych itp.).

Dla elity rządzącej ostatniej fali charakterystyczny jest również wzrost odsetka krajanów głowy państwa (z 13,2\% za czasów Jelcyna do 21,3\% za czasów Putina) oraz wzrost udziału biznesmenów (z 1,6\% w okresie władzy Jelcyna do 11,3\% w okresie władzy Putina $)^{18}$.

Charakteryzując mentalność polityczną rosyjskiej elity rządzącej, wielu badaczy podkreśla jej immoralizm i „lokajstwo” („холопство”). Na przykład Oksana Gaman-Gołutwina zaznacza, że kult sity pozostaje dominująca cecha postawy zarówno wtadz centralnych, regionalnych, jak i spoteczeństwa ${ }^{19}$. Prowadzi to, z jednej strony, do bezwarunkowej lojalności wobec Prezydenta, a z drugiej - do stałego przedkładania interesów klanowych nad narodowe.

Badacze wyrażają zaniepokojenie obecnym potencjałem strategicznym elity, powołanej do ochrony społeczeństwa i poprawy jego stopy życiowej. Tatiana Zasławska sądzi, że elicie udato się stworzyć takie reguty gry, które zapewniaja jej brak kontroli ze strony spoteczeństwa i brak odpowiedzialności wobec niego. Rezultatem jest pogtębienie wzajemnej alienacji wtadzy ispoteczeństwa, przejawiajacej się, z jednej strony w obojętności wtadzy na nieszczęścia narodu, a z drugiej - w catkowitej nieufności narodu w stosunku do przedstawicieli i instytutów wtadzy ${ }^{20}$.

18 О. Крыштановская, Анатомия..., s. 264.

19 О. Гаман-Голутвина, Бюрократия или олигархия?, [w:] Kуда идет Pоссия?... Bласть, общество, личность, red. Т. Заславская, Москва 2000, s. 172. 
Współczesna elita rządząca w Rosji ma w dużej mierze charakter korporacyjny. Najpotężniejszymi korporacjami są obecnie grupy finansowo-przemysłowe posiadające ogromne zasoby kapitałowe, kontrolujące najważniejsze przedsiębiorstwa i produkcję, stopniowo monopolizujące rynek medialny i tym samym - mogące wpływać na proces decyzyjny kanałami rządowymi i parlamentarnymi. System korporacyjny w Rosji opiera się na współzależności najbardziej wpływowych grup interesów oraz państwa i ma charakter umowny. Na przykład były rząd Wiktora Czernomyrdina, sprzyjając korporacji „Gazprom”, otrzymywał w zamian możliwość rozwiązywania problemów polityki społecznej z jej pomocą.

Tatiana Zasławska odnotowuje, że $w$ rezultacie „rynkowych" reform podstawowych instytucji państwo rozptynęto się w prywatnych korporacjach polityczno-finansowych [...] Za każda grupa ministerstw, regionów, kompleksów przemystowym Rosji stoi określony klan rzadzacy ${ }^{21}$. W wyniku celowych działań tych korporacji władza państwowa może okazać się zakładnikiem grupy monopolistów polityczno-gospodarczych, podlegać bezpośrednim naciskom ze strony przedstawicieli interesów prywatnych. Może to doprowadzić do oligarchizacji systemu politycznego i wzrostu napięć społecznych w kraju.

Siergiej Pieriegudow zidentyfikował kilka kluczowych rozwiązań, które mogłyby sprawić, że korporacjonizm nie będzie podważał, lecz wzmacniał demokrację i pokój społeczny: Po pierwsze, to istnienie samodzielnych, niezależnych od państwa grup interesów oraz ich ukierunkowanie na relacje z nim w celu wzmocnienia partnerstwa spotecznego i poprawy efektywności ekonomicznej. Po drugie, to określony stopień instytucjonalizacji wspomnianych relacji $i$ zdolność państwa do "narzucenia" w procesie negocjacji priorytetów, dyktowanych przez interesy narodowe. I wreszcie, po trzecie, to przestrzeganie przez wszystkie strony powziętych zobowiazań oraz odpowiedni system kontroli ich realizacji22.

Wymienione zasady przetransponowane do sfery politycznej mogłyby osłabić negatywne skutki korporacjonizmu politycznego.

Obecnie toczy się walka wewnętrzna między różnymi grupami rosyjskiej elity rządzącej, ale te konflikty nie są tak poważne, jak w Liberii, Sierra Leone etc., z wyjątkiem roku 1993, kiedy konflikt między parlamentem a prezydentem znalazł wyraz w użyciu siły. W wyborach prezydenckich w latach: 2000, 2004, 2008 i 2012 rosyjska elita rządząca występowała jako dosyć zwarta grupa i właściwie trudno powiedzieć, że istniała jakaś poważna opozycja dla jej kandydata.

Wszystko to pokazuje, że w rosyjskiej elicie istnieje obecnie dominująca grupa, która skupia w swoich rękach całą władzę w państwie i na zasadzie monopolu określa politykę wewnętrzną i zewnętrzną.

W ramach systemu demokracji sterowanej, odziedziczonej przez Putina po Jelcynie, elity dysponowały takimi instytucjonalnymi elementami demokracji, jak partie polityczne, wybory i media, działające w jednym celu, aby pomóc elicie rządzącej zachować

21 Tamże, s. 291.

22 С. Перегудов, Новый российский корпоративизм: демократический или бюрократический?, „Полис" 1997, nr 2, s. 24. 
władzę. W kraju odbywały się regularne wybory, ale nie zapewniały one możliwości przekazania władzy, lecz tylko legitymowały władzę już istniejącą.

Celem demokracji sterowanej jest nie tyle ustanowienie monopolu na władzę, ile monopolizacja procesu ubiegania się o nią. Strategia systemu polegała na utrzymaniu iluzji reprezentacji politycznej i jednocześnie uniemożliwieniu realizacji interesów i intencji opozycji. Model demokracji sterowanej uniezależnił elity od uzasadnionych żądań obywateli. Prawie wszystkie reformy przeprowadzone w Rosji, w warunkach demokracji sterowanej, były zainicjowane z góry. Właśnie owo powszechne lekceważenie fundamentalnych potrzeb ludzi stanowi najbardziej oburzającą wadę tego systemu politycznego.

We współczesnej Rosji elita rządząca przejęła kontrolę nad kluczowymi sektorami gospodarki, mediami, budowaniem systemu partyjnego, tworzy struktury, które mogą aktywnie wspierać ją w momentach kryzysu (np. ruch „Nasi” [„Наши”]).Z punktu widzenia dzisiejszej rosyjskiej elity rządzącej suwerenność Rosji to możliwość, realizowana przy założeniu istnienia niezależności ekonomicznej, potęgi wojskowej i tożsamości kulturowej, tożsamości rządzących i rządzonych. W związku z tym dla rosyjskiej elity rządzącej wybory nie stanowią instrumentu wyrażania różnych sprzecznych interesów, lecz demonstrację jedności władających i rządzonych.

Obecny system społeczny, koncentrując władzę i majątek w rękach małych grup elity będącej u władzy, jest niestabilny. Jego stabilność zostaje zwiększona kosztem rozszerzenia klienteli, obsługującej klany oligarchiczne i dlatego zainteresowanej zachowaniem systemu. Jednak główna część elity nadal zorientowana jest na redystrybucję majątku, co prowadzi do ostrych konfliktów wewnętrznych, które zagrażają „wywróceniem tódki”.

W relacjach ze społeczeństwem elita rządząca dla realizacji swojego panowania wykorzystuje przede wszystkim takie mechanizmy, jak manipulowanie świadomością zbiorową za pośrednictwem telewizji, „adresowane” strumienie finansowe i selektywną represyjność.

Wpływ organów przedstawicielskich we współczesnej Rosji w praktyce ogranicza się do funkcji doradczych wobec administracji prezydenta i Rady Ministrów. Ale w systemie pluralistycznym, nawet krańcowo zbliżonym do autorytarnego, funkcje doradcze są również ważne jako kanał lobbowania. Sprzeczne wektory nacisku na deputowanych i propozycje „nie do odrzucenia”, prowadzą do niebywałej zawiłości ustawodawstwa, co gwarantuje urzędnikom niemal nieograniczone możliwości nadużyć w działaniach. W reakcji na to ludność również otrzymuje szerokie możliwości sabotowania inicjatyw władzy, ale jest praktycznie bezbronna wobec bezprawia grup biznesowych mających urzędniczą osłonę. Przenosi to rozwiązywanie sprzeczności społecznych z dziedziny prawa do sfery konfrontacji siłowej, instalując pod całym systemem nowe miny, grożące przyszłymi wybuchami społecznymi.

Ścisłe powiązanie różnych gałęzi i sektorów władzy wyklucza „podział władzy”, ale jednocześnie umożliwia społeczeństwu wykorzystanie konfliktów interesów różnych grup urzędników uwarunkowanych względami resortowymi, komercyjnymi oraz odmiennymi orientacjami w polityce zagranicznej. Na tej podstawie powstają i rozwijają się istniejące partie parlamentarne lub pretendujące do reprezentacji w parlamencie. Prawdziwe różnice ideologiczne między tymi partiami nie są tak istotne, jak przekonują ich służby piarowskie, i wpisują się w to samo spektrum co różnice między grupami 
rządzącymi (od socjal-konserwatyzmu Komunistycznej Partii Federacji Rosyjskiej do neoliberalizmu Sojuszu Sił Prawicowych).

Powyższe fakty niezaprzeczalne świadczą przede wszystkim o tym, że rządzące grupy elity zawsze odgrywały kluczową rolę w historii Rosji. Elita przedrewolucyjna stanowiła zamkniętą kastę, do której przepustką był nie rozum, lecz przynależność do wyższych sfer, gdzie kwitł nepotyzm, klanowość, kumoterstwo, przekupstwo, korupcja. Przy tym owa elita miała ogromny wpływ na podejmowanie wszystkich najważniejszych decyzji państwowych, co często niosło negatywne skutki dla społeczeństwa rosyjskiego. Na początku XX w. w Rosji carskiej ujawnił się niezwykle głęboki kryzys elity politycznej, która straciła wszelką wiarygodność w oczach mas.

Głównym problemem współczesnego społeczeństwa rosyjskiego jest optymalizacja relacji elity i obywateli, aby priorytetem stały się interesy obywateli, mieszkańców Rosji (elita dla narodu, a nie naród dla elity). Ważna jest również inna kwestia - relacje pomiędzy grupami w obrębie elity i między elitami. Dla stabilności systemu politycznego korzystniejsza jest jednolita elita. Starcia w elitach to zagrożenie dla stabilności. Równocześnie istnienie w elicie konkurujących grup jest korzystne dla demokracji: grupy te są zmuszone do poszukiwania poparcia mas, których rola rośnie - to one stają się arbitrem.

Należy pamiętać, że elity mają swoje interesy partykularne, które nie pokrywają się $\mathrm{z}$ interesami większości obywateli. Współczesna elita rosyjska ma własną subkulturę, własne standardy życiowe, własne preferencje, własną mentalność, własną orientację wartościującą (w przeważającej mierze prozachodnią).

Dla współczesnego rosyjskiego systemu politycznego nie są korzystne skrajności elitaryzmu czy egalitaryzmu, lecz demokratyczne optimum w relacjach między masą i elitą, gdzie „buforem” i jednym z filarów stabilności jest klasa średnia, której formowanie uległo obecnie znacznemu spowolnieniu. Aby uniknąć zakłóceń w relacjach między elitami i zwykłymi obywatelami we współczesnym społeczeństwie rosyjskim, konieczne jest, przede wszystkim, ukształtowanie pełnowartościowego społeczeństwa obywatelskiego, które wyłoniłoby swoją nieformalną elitę i zaczęło ściśle kontrolować elitę rządzącą. Gdy istnieje pełnowartościowe społeczeństwo obywatelskie, to nie elita dysponuje narodem, lecz naród wynajmuje administratorów politycznych, menedżerów, aby ci skutecznie zarządzali społeczeństwem w interesie większości, i zwalnia tych administratorów, jeśli nie spełniają powierzonych funkcji. Otworzy to perspektywy nie dla kontrolowanej, lecz autentycznej demokracji.

Tłumaczenie: Magdalena Romanowska

\section{BIBLIOGRAFIA}

Баранов Н., Правящщая әлита современной России, „Без темы. Научный общественно-политический журнак" 2006, nr 2.

Вира, [w:] Энщиклопедический Словарь Ф. А. Брокгауза и И. А. Ефрона, Санкт-Петербург 1890-1907, [online] http://www.vehi.net/brokgauz/. 
Волость, [w:] Энщиклопедический Словарь Ф. А. Брокгауза и И. А. Ефрона, Санкт-Петербург 1890-1907, [online] http://www.vehi.net/brokgauz/.

Восленский М., Номенклатура, Москва 2005.

Гаман-Голутвина О., Бюрократия или олигархия?, [w:] Kуда идет Россия?... Bласть, общество, личность, red. Т. Заславская, Москва 2000.

Гаман-Голутвина О., Политические элиты России. Вехи исторической эволючии, Москва 1998, Политология России.

Грановский С., Прикладная политология. Учебное пособие, Москва 2004.

Ажилас М., Аицо тоталитаризма, przeł. П. Щетинин, Е. Полак, О. Киримлова, Москва 1992.

Заславская Т., Современное российское общество. Сочиальньий механизм трансформачии, Москва 2004.

Исаеев И. А., История государства и права России, Москва 2004.

КАючевский В., Сочинения в девяти томах. Курс русской истории, Москва 1988.

Крыштановская О., Анатомия российской элиты, Москва 2005.

М. А., Кормление, [w:] Энииклопедический Словарь Ф. А. Брокгауза и И. А. Ефрона, Санкт-Петербург 1890-1907, [online] http://www.vehi.net/brokgauz/.

Моска Г., Правящий класс, „Социологические исследования” 1994, nr 10.

Перегудов С., Новъй российский корпоративизм: демократический или бюрократический?, „Полис" 1997, nr 2.

Сорокин П., Человек, цивилизачия, общество, Москва 1992.

УАарцев С., Политическая и правовая теория анархизма в России. История и современность, Москва 1994.

Шнайдер Э., Политическая система Российской Федерации, Москва 2002.

Bazylow L., Historia Rosji, t. 1, Warszawa 1983.

Müller J.-W., A Dangerous Mind. Carl Schmitt in Post-War European Thought, New Haven-London 2003.

Ochmański J., Dzieje Rosji do roku 1861, Warszawa 1986.

Rosanvallon P., Democracy Past and Future, red. S. Moyn, New York 2006, Columbia Studies in Political Thought/Political History.

Aleksandr Pawłowicz KOCZETKOW - doktor nauk filozoficznych, profesor w Katedrze Polityki Rosyjskiej na Wydziale Politologii Moskiewskiego Uniwersytetu Państwowego im. M. Łomonosowa. 